Article

\title{
The Essential Oils from Pittosporum tobira Flowers Display Antiproliferative Properties and Inducing Apoptosis on Lung Carcinoma Cells
}

\author{
Yan-Fang Sun ${ }^{1, *}$, Michael Wink ${ }^{2}$, Zhang-Qi Wang', Hong-Fei Lu' ${ }^{1}$, Peng-Guo Xia ${ }^{1}$, Hong-Tao Liu ${ }^{1}$, \\ Shi-Xian Wang ${ }^{1}$, Yang Sun ${ }^{3, *}$ and Zong-Suo Liang1,*
}

${ }^{1}$ Key Laboratory of Plant Secondary Metabolism and Regulation of Zhejiang Province, College of Life Sciences, Zhejiang Sci-Tech University, Hangzhou 310018, China;

2Institute of Pharmacy and Molecular Biotechnology, Heidelberg University, Im Neuenheimer Feld 364, 69120 Heidelberg, Germany;

${ }^{3}$ College of Resource and Civil Engineering, Northeastern University, Shenyang 110819, China;

wink@uni-heidelberg.de (M.W.); wzqkkkk@163.com (Z.-Q.W.); luhongfei0164@163.com (H.-F.Lu); 621836511@qq.com (P.-G.Xia); 2594071388@qq.com (H.-T.Liu); 1850888916@qq.com (Sh.-X.Wang);

"Correspondence:katherineyfs@sina.com(Y.-F.Sun);liangzs@ms.iswc.ac.cn(Z.-S.Liang);

sunyang2017ZSTU@163.com (Y.Sun);

Tel./Fax: +86-537-8684-3187

"The co-corresponding authors

\begin{abstract}
:
Background: Pittosporum tobira (Thunb.) Aiton is an aromatic medicinal plant widely cultivated in the world. However, the essential oils (EOs) from P. tobira flowers for anti-cancer potential is still not systematically studied. The present aim to elucidate the phytochemical composition of the EOs and to explore mechanism of anticancer action. Methods: The EOs were extracted and analyzed by headspace solid-phase microextraction (HS-SPME) with gas chromatography-mass spectrometry (GC-MS). Volatile components were identified according to Kovats retention index (KI) and NIST database. The anti-neoplasm mechanisms of the EOs was comprehensively investigated in lung carcinoma A549 and H460 cells. Results: A total of 47 secondary metabolites representing $94.18 \%$ of the EOs were successfully identified: monoterpenes and sesquiterpenes were the dominant terpenoids. The EOs exhibited antiproliferative activity on A549 and H460 lung carcinoma cells. Hoechst 33324 fluorescent staining indicated the typical characteristics of apoptosis and induced cycle phase arrest. AnnexinV/PI staining revealed that the number of apoptotic cells was increased. Furthermore, the EOs also induced the caspase-mediated mitochondrial apoptosis pathway. Conclusions: Findings suggest that the full-scale chemical composition and first characterization of anticancer activities of the EOs, it could be used for integrative natural anti-cancer agents in health care should be pay more attention.
\end{abstract}

Keywords:

Pittosporum tobira (Thunb.) Aiton; Essential oils (EOs); Headspace solid-phase microextraction (HS-SPME); Gas chromatography-mass spectrometry (GC-MS); Anticancer activity 


\begin{abstract}
Abbreviations:
EOs: essential oils; $H S-S P M E$ : headspace solid-phase microextraction; GC-MS: gas chromatography-mass spectrometry; $I C_{50:}$ 50\% inhibitory concentration; MTT assay:

4,5-dimethyl-2-thiazolyl)-2,5-diphenyl-2-H-tetrazolium bromide assay; SDS-PAGE: SDS-polyacrylamide gel electrophoresis.
\end{abstract}

\title{
1. Introduction
}

Pittosporum tobira (Thunb.) Aiton belongs to the Pittosporaceae family that originates from East Asia, but is presently being cultivated as ornamental plant in many parts of the world [1] because it is resistant to pollution and environmental stress [2,3]. The inflorescence is a cluster of fragrant flowers sitting at the end of branches. The flowers have five pure white petals which gradually turn yellow [4]. The significant feature of this evergreen tree with thick leathery leaves is its prominent scent of flower; also named "Bói lị xíang" in Chinese [5]. The volatile oils from P. tobira flowers has been many studied before [6], main components are $\alpha$-pinene, n-nonane, nerolidol and $\beta$-ocimene [7]. However, the composition varies strongly between origins [8]. Differences in chemical compositions can affect the biological activities of volatile oils, which include anti-inflammation [9], anti-fungal [10], antioxidant [11] and anticancer activities [12]. The present study mainly focused on the phytochemical analysis of the EOs from P. tobira flowers cultivated in China. Furthermore, we firstly studied the antiproliferative potentials of the EO against the human non-small cell lung cancer cell lines A549 and H460.

\section{Results}

\subsection{Phytochemical composition of the EOs}

In the present work, the total of 47 components representing $94.18 \%$ of the EOs were identified according to KI value and NIST11 database (Figure a, Table 1). The main components were monoand sesquiterpenes, including $\beta$-pinene, $\beta$-myrcene, $\gamma$-elemene, $\beta$-ocimene, $D$-limonene and nerolidol as major components (Figure b).

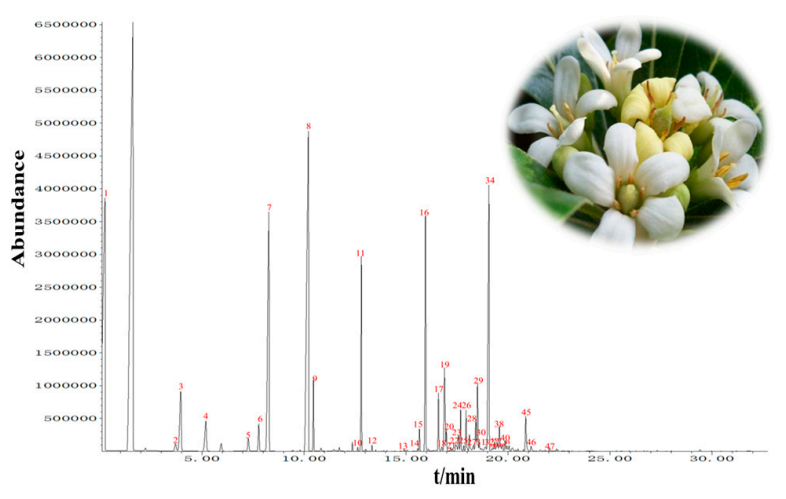

(a)
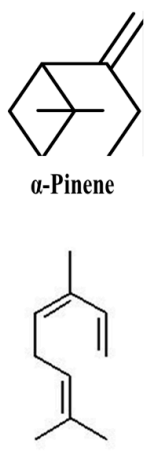

$\beta$-0cimene

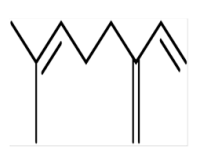

$\beta$-Myrcene

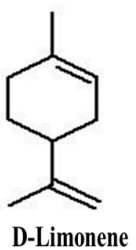

(b)

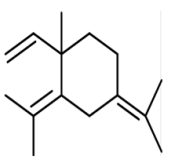

Г-Elemene

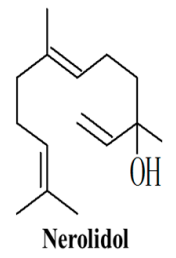

Figure 1. (a) GC-MS profile of the EOs from P. tobira. flower; (b) The main compounds of the EO are $\alpha$-pinene

(No. 2) , $\beta$-myrcene (No.6), $\gamma$-elemene (No.16), $\beta$-ocimene (No.17), D-limonene (No. 5) and nerolidol

(No. 45) as shown in the chromatogram.

Table 1. Phytochemical composition of the EO from P. tobira flowers via HS-SPME/GC-MS.

\begin{tabular}{cccccc}
\hline $\begin{array}{c}\text { Peak } \\
\text { no. }\end{array}$ & Compound & $\begin{array}{c}\text { Relative } \\
\text { content } \mathbf{( \% )}\end{array}$ & $\begin{array}{c}\text { Molecular } \\
\text { formula }\end{array}$ & $\begin{array}{c}\text { Molecular } \\
\text { weight }\end{array}$ & ${\text { KI }{ }^{\mathbf{1}}}$ \\
\hline 1 & n-Nonane & 12.61 & $\mathrm{C}_{9} \mathrm{H}_{20}$ & 128 & 899 \\
2 & $\alpha$-Pinene & 1.64 & $\mathrm{C}_{10} \mathrm{H}_{16}$ & 136 & 914 \\
\hline
\end{tabular}




\begin{tabular}{|c|c|c|c|c|c|}
\hline 3 & Camphene & 3.51 & $\mathrm{C}_{10} \mathrm{H}_{16}$ & 136 & 925 \\
\hline 4 & $\beta$-Phellandrene & 1.30 & $\mathrm{C}_{10} \mathrm{H}_{16}$ & 136 & 1018 \\
\hline 5 & D-Limonene & 0.49 & $\mathrm{C}_{10} \mathrm{H}_{16}$ & 136 & 1028 \\
\hline 6 & $\beta$-Myrcene & 0.75 & $\mathrm{C}_{10} \mathrm{H}_{16}$ & 136 & 1032 \\
\hline 7 & trans- $\beta$-Ocimene & 17.43 & $\mathrm{C}_{10} \mathrm{H}_{16}$ & 136 & 1052 \\
\hline 8 & n-Undecane & 11.88 & $\mathrm{C}_{11} \mathrm{H}_{24}$ & 156 & 1060 \\
\hline 9 & n-Dodecane & 2.83 & $\mathrm{C}_{12} \mathrm{H}_{26}$ & 160 & 1087 \\
\hline 10 & Dodecane & 0.06 & $\mathrm{C}_{12} \mathrm{H}_{26}$ & 170 & 1089 \\
\hline 11 & $\begin{array}{l}\text { 3,7-dimethyldeca } \\
\text { ne }\end{array}$ & 3.61 & $\mathrm{C}_{12} \mathrm{H}_{26}$ & 160 & 1096 \\
\hline 12 & $\begin{array}{l}\text { Cyclohexyl } \\
\text { benzene }\end{array}$ & 0.11 & $\mathrm{C}_{12} \mathrm{H}_{16}$ & 160 & 1109 \\
\hline 13 & $\mathrm{n}$-Tridecane & 0.03 & $\mathrm{C}_{13} \mathrm{H}_{28}$ & 184 & 1113 \\
\hline 14 & $\gamma$-Terpinene & 0.05 & $\mathrm{C}_{10} \mathrm{H}_{16}$ & 136 & 1116 \\
\hline 15 & cis-Thujopsene & 0.81 & $\mathrm{C}_{15} \mathrm{H}_{24}$ & 204 & 1118 \\
\hline 16 & $\gamma$-Elemene & 5.03 & $\mathrm{C}_{15} \mathrm{H}_{24}$ & 204 & 1138 \\
\hline 17 & $\beta$-Ocimene & 1.19 & $\mathrm{C}_{15} \mathrm{H}_{24}$ & 204 & 1146 \\
\hline 18 & Cedarene & 0.14 & $\mathrm{C}_{15} \mathrm{H}_{24}$ & 204 & 1152 \\
\hline 19 & $\beta$-Guaiene & 2.27 & $\mathrm{C}_{15} \mathrm{H}_{24}$ & 204 & 1158 \\
\hline 20 & Calarene & 0.41 & $\mathrm{C}_{15} \mathrm{H}_{24}$ & 204 & 1174 \\
\hline 21 & $\alpha$-Longipinene & 0.08 & $\mathrm{C}_{15} \mathrm{H}_{24}$ & 204 & 1183 \\
\hline 22 & $\alpha$-Cubebene & 0.26 & $\mathrm{C}_{15} \mathrm{H}_{24}$ & 204 & 1198 \\
\hline 23 & Caryophyllene & 0.39 & $\mathrm{C}_{14} \mathrm{H}_{22}$ & 190 & 1205 \\
\hline 24 & $\alpha$-Copaene & 0.82 & $\mathrm{C}_{15} \mathrm{H}_{24}$ & 204 & 1217 \\
\hline 25 & $\beta$-Copaene & 0.12 & $\mathrm{C}_{15} \mathrm{H}_{24}$ & 204 & 1222 \\
\hline 26 & Calarene & 0.84 & $\mathrm{C}_{15} \mathrm{H}_{24}$ & 204 & 1236 \\
\hline 27 & $\alpha$-Muurolene & 0.19 & $\mathrm{C}_{15} \mathrm{H}_{24}$ & 204 & 1243 \\
\hline 28 & $\beta$-Bourbonene & 0.72 & $\mathrm{C}_{15} \mathrm{H}_{24}$ & 204 & 1258 \\
\hline 29 & Caryophyllene & 1.42 & $\mathrm{C}_{15} \mathrm{H}_{24}$ & 204 & 1267 \\
\hline 30 & a-Longipinene & 0.14 & $\mathrm{C}_{15} \mathrm{H}_{24}$ & 204 & 1273 \\
\hline 31 & $\begin{array}{l}\text { Alloaromadendre } \\
\text { ne }\end{array}$ & 0.14 & $\mathrm{C}_{15} \mathrm{H}_{24}$ & 204 & 1284 \\
\hline 32 & (-)- $\beta$-Chamigrene & 0.09 & $\mathrm{C}_{15} \mathrm{H}_{24}$ & 204 & 1296 \\
\hline 33 & $\gamma$-Muurolene & 0.12 & $\mathrm{C}_{15} \mathrm{H}_{24}$ & 204 & 1317 \\
\hline 34 & $\beta$-Copaene & 15.01 & $\mathrm{C}_{15} \mathrm{H}_{24}$ & 204 & 1325 \\
\hline 35 & Widdrene & 0.04 & $\mathrm{C}_{15} \mathrm{H}_{24}$ & 204 & 1349 \\
\hline 36 & $\alpha$-Copaene & 0.08 & $\mathrm{C}_{15} \mathrm{H}_{24}$ & 204 & 1357 \\
\hline 37 & Muurolene & 0.08 & $\mathrm{C}_{15} \mathrm{H}_{24}$ & 204 & 1372 \\
\hline 38 & $\alpha$-Cubebene & 1.10 & $\mathrm{C}_{15} \mathrm{H}_{24}$ & 204 & 1389 \\
\hline 39 & Germacrene & 0.19 & $\mathrm{C}_{15} \mathrm{H}_{24}$ & 204 & 1440 \\
\hline
\end{tabular}


4 of 10

\begin{tabular}{ccclll}
\hline 40 & $\gamma$-Elemene & 0.21 & $\mathrm{C}_{15} \mathrm{H}_{24}$ & 204 & 1447 \\
41 & $\alpha$-Farnesene & 0.49 & $\mathrm{C}_{15} \mathrm{H}_{24}$ & 204 & 1494 \\
42 & $\gamma$-Himachalene & 0.14 & $\mathrm{C}_{15} \mathrm{H}_{24}$ & 204 & 1498 \\
43 & $\delta$-Cadinene & 0.33 & $\mathrm{C}_{15} \mathrm{H}_{24}$ & 204 & 1512 \\
44 & $\alpha$-Muurolene & 0.18 & $\mathrm{C}_{15} \mathrm{H}_{24}$ & 204 & 1523 \\
45 & Nerolidol & 3.92 & $\mathrm{C}_{15} \mathrm{H}_{26} \mathrm{O}$ & 222 & 1564 \\
46 & Ledol & 0.92 & $\mathrm{C}_{15} \mathrm{H}_{26} \mathrm{O}$ & 222 & 1530 \\
47 & $\alpha$-Cedrene & 0.05 & $\mathrm{C}_{15} \mathrm{H}_{26} \mathrm{O}$ & 204 & 1540 \\
& Monoterpenes & 24.06 & & & \\
& Sesquiterpenes & 32.65 & & & \\
& Alkanes & 32.12 & & & \\
& Others & 5.35 & & & \\
& Total components & 94.18 & & & \\
\hline
\end{tabular}

${ }^{1} \mathrm{KI}$, Relative retention index was calculated against n-alkanes $\left(\mathrm{C}_{8}-\mathrm{C}_{20}\right)$ on DB-5 column.

\subsection{Cell viability and fluorescent nuclear staining}

MTT assay was used to investigate cell viability of A549 and H460 cells and shown in Figure 2a, EOs treatment resulted in a significant dose-dependent inhibition of the growth of A549 and H460 cells, and the IC50 values were $27.34 \pm 1.69$ and $38.06 \pm 4.18 \mu \mathrm{L} / \mathrm{mL}$, respectively. A549 and H460 cells were stained with the cell permeable DNA dye by Hoechst 33342, to examine the nuclear morphological changes by fluorescent microscopy (Figure $2 b$ ). Faintly stained, round and intact nuclei were observed in the control group, indicating typical healthy cells. However, the EOs treated groups exhibited a gradually increasing degree of apoptosis with evident morphological changes, such as improved brightness, gradually condensing and marginalized chromatin, fragmented nucleus.

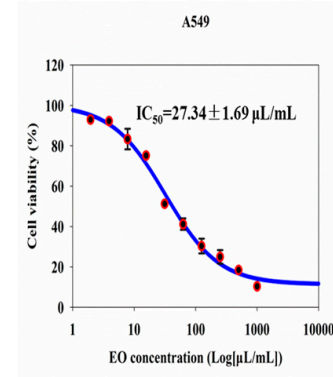

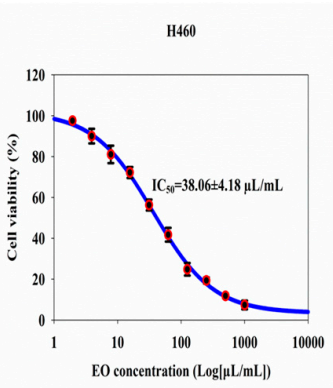

(a)
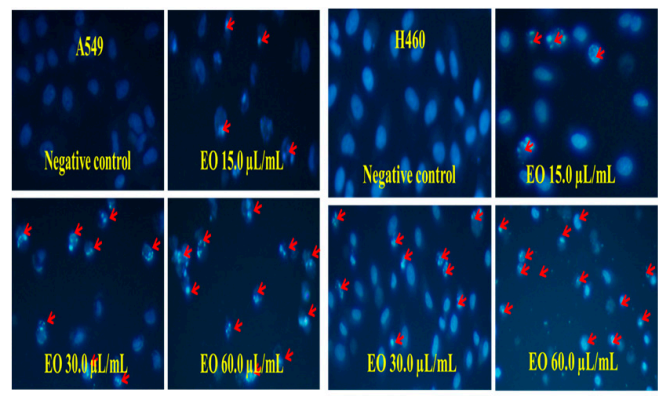

(b)

Figure 2. (a) Antiproliferative effects of the EOs on A549 and H460 cells by MTT assay. A549 and H460 cells were treated with various concentrations of the EOs for $24 \mathrm{~h}$. The results represented the average of three independent experiments \pm S.D.(b) Morphological observation by inverted fluorescence microscopy of A549 and H460 cells stained with Hoechst 33342. Photomicrographs of fluorescence staining were randomly examined with a magnification of 40 . Apoptotic cells containing fragmented nuclear chromatin are indicated by red arrows.

\subsection{Effect of the EOs on apoptosis and cell cycle distribution}

To quantify the extent of apoptosis, A549 and H460 cells treated with the EOs were stained with Annexin V-FITC/PI followed by flow cytometry analysis. After treatment with the EOs for $24 \mathrm{~h}$, the percentages of both early and late apoptotic cells gradually increased in a dose dependent fashion. The percentages of A549 cells undergoing apoptosis following treatment with 0, 15.0, 30.0 and 60.0 
$\mu \mathrm{L} / \mathrm{mL}$ EOs (including the early and late apoptotic cells) were $0.6 \pm 0.19 \%, 22.0 \pm 0.67 \%, 31.6 \pm 1.58 \%$ and $92.7 \pm 3.25 \%$ (Figure 3a). Similarly, the apoptosis rates of $\mathrm{H} 460$ were $1.5 \pm 0.34 \%, 27.10 \pm 0.59 \%$, $36.5 \pm 1.20 \%$ and $45.2 \pm 1.07 \%$ (Figure $3 \mathrm{~b}$ ). Therefore, EOs promoted A549 and H460 cell apoptosis in a dose-dependent manner via externalization of phosphatidylserine (PS), which is characteristics features of cancer cell apoptosis.

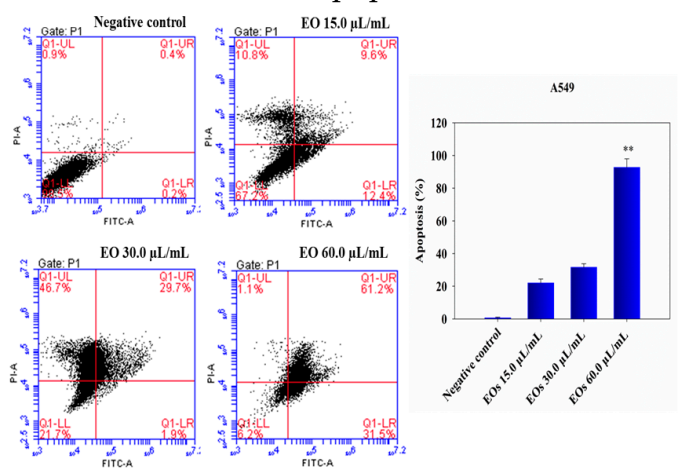

(a)

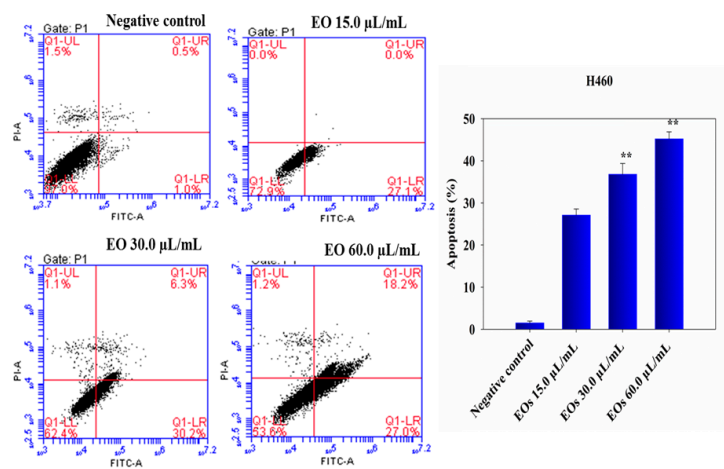

(b)

Figure 3. EO induced apoptosis in A549 (a) and H460 cells (b) were detected from labeled Annexin V-FITC/PI by flow cytometric histogram analyses. Columns show mean values of three experiments expressed as mean \pm S. D. $(n=3)$. Statistical analyses were performed by Student's $t$-test $\left({ }^{*} P<0.05,{ }^{* *} P<\right.$ 0.01 ) compared with the negative control group.

\subsection{Effect of the EOs on cell cycle distribution}

A549 and H460 cells were stained with PI. The percentages of cells in the G0/G1 phase with a hypodiploid DNA histogram decreased from roughly $43.94 \%$ (negative control) to $13.85 \%$ for A549 and from $46.94 \%$ to $12.67 \%$ for $\mathrm{H} 460$ cells, respectively (Figure 4a). Subsequently, the number of cells in the G2/M phase also correspondingly elevated from $6.63 \%$ to $49.09 \%$ for A549 and from $9.81 \%$ to $40.12 \%$ for H460 cells, respectively (Figure $4 \mathrm{~b}$ ). The EOs decreased the percentages of cells in the G0/G1 phase in a dose-dependent manner and significantly increased the percentages of cells in the G2/M phase in both cell lines. These data indicate that the EOs specifically induced cell cycle checkpoints and suppressed the reproduction of cancer cells associated with cycle arrest.

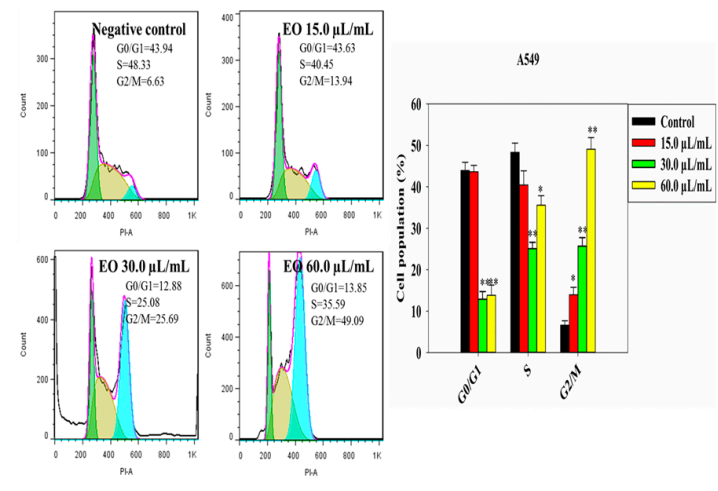

(a)
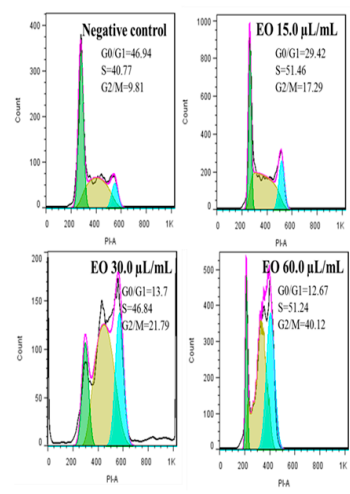

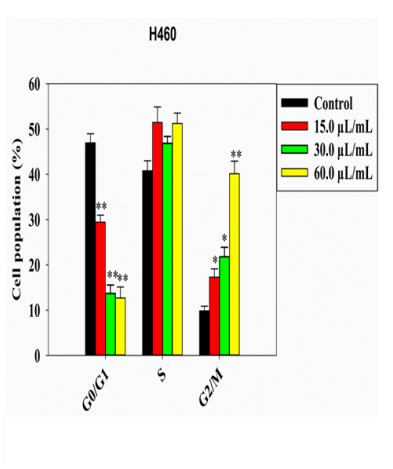

(b)

Figure 4. Effect of the EOs on cell cycle in A549 (a) and H460 cells (b) stained with PI and analyzed on FL2-A channel of flow cytometer equipped with $488 \mathrm{~nm}$ laser. The X-axis represents the DNA content and the Y-axis represents the cell counts. The graph depicts the percentage of apoptotic cells. Columns show mean values of three independent experiments expressed as mean \pm S. D. $(n=3)$. Statistical analyses were performed by Student's $t$-test $\left({ }^{*} P<0.05,{ }^{* *} P<0.01\right)$ compared to untreated control. 
6 of 10

\subsection{Apoptotic signaling pathways}

A549 and $\mathrm{H} 460$ cells were treated with increasing concentrations of EOs for $48 \mathrm{~h}$. The expression of Bcl-2, Bax, Caspase-3, Caspase-8, Caspase-9 and PARP were determined by Western blotting. Apparently, expressions of the apoptotic proteins Bax and Caspase-3 were up-regulated, whereas expressions of anti-apoptotic proteins Bcl-2, PARP, Caspase-8 and Caspase-9 were down-regulated (Figure 5a). The EOs could elicit apoptosis in A549 and H460 cells via caspase-dependent pathway (Figure 5b). The EOs comprises a large number of different components so that their mode of action can involve several mechanisms for inhibition of A549 and H460 cells in non-small cell lung carcinoma.

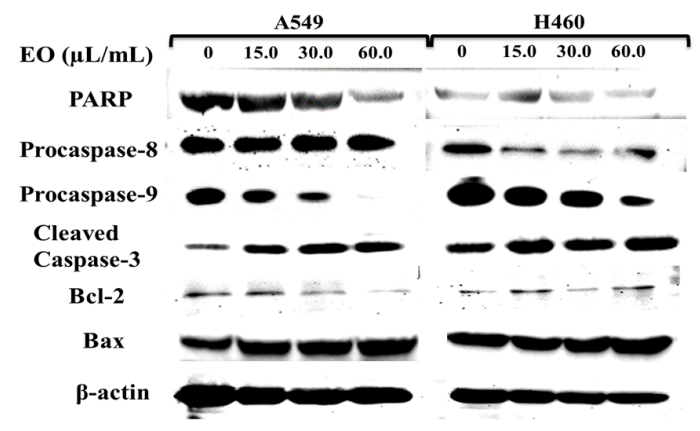

(a)

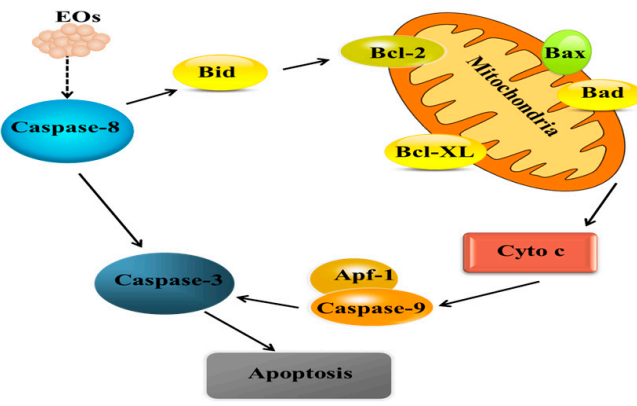

(b)

Figure 5. (a) Caspase induced cleavage of PARP, Caspase-3, Caspase-8, Caspase- 9 as well as Bax and Bcl-2 expression in A549 and $\mathrm{H} 460$ cells were determined through western blotting after $48 \mathrm{~h}$ treatment. $\beta$-actin served as loading control. (b) The schematic diagram illustrates how the EOs could regulate mitochondrial control of apoptosis pathway in lung cancer cells.

\section{Discussion}

In our present phytochemical investigation on the EOs from $P$. tobira flowers growing in China, we found that natural terpenoids dominated the oil with $56.7 \%$ consisting to $24.1 \%$ monoterpenes $\left(\mathrm{C}_{10} \mathrm{H}_{16}\right)$ and $32.7 \%$ sesquiterpenes $\left(\mathrm{C}_{15} \mathrm{H}_{24}\right)$. Especially monoterpenes and sesquiterpenes appear to be responsible for the anticancer activity in several medicinal plants. The main compounds of EOs such as $\alpha$-humulene, $\beta$-caryophyllene, myrcene and $\beta$-pinene exhibited popularbioactivities against fungal infectious diseases, viruses and tumors $[13,14]$. Camphene isolated from Piper cernuum EO exerted antitumor activity against melanoma cells [15]. Limonene and $\beta$-elemene can be regarded as broad-spectrum antitumor agents [16-18]. These volatile compounds could contribute to inhibit lung tumor cell proliferation; however, data from animals experiments are needed to validate this assumption.

In addition, EOs induced A549 and H460 cells apoptosis and mediated the mitochondrial apoptosis pathway by up-regulation the level of Bax and down-regulation of Bcl-2. It is well known that mitochondrial pathway is the best known intrinsic apoptosis pathway. The mitochondrion is the main site of action for members of the apoptosis-regulating protein family, the balance of Bax and Bcl-2 plays a critical role in mitochondrial apoptosis process [19].

\section{Materials and Methods}

\subsection{Experimental materials}

Flowers of $P$. tobira were collected from the campus of Zhejiang Sci-Tech University during the flowering season in May, 2015-2016, and identified by Prof. Hongfei Lu of Botany Taxonomy. 
Voucher specimens (No. PP2016050649) were deposited at the Laboratory of Plant Secondary Metabolism and Regulation of Zhejiang Province, China.

Human non-small cell lung cancer cell lines A549 and H460 were obtained from the Chinese Academy of Sciences, Shanghai Institutes for Cell Resource Center. The cell lines were maintained on Dulbecco's modified Eagle high glucose medium (Gibco, USA), supplemented with $10 \%$ fetal bovine serum (Hyclone, USA), $100 \mathrm{U} / \mathrm{mL}$ penicillin and $100 \mathrm{U} / \mathrm{mL}$ streptomycin. The cells were cultured in an incubator with $5 \% \mathrm{CO}_{2}$ and $95 \%$ humidity; the experiments were performed with cells in the logarithmic growth phase.

\subsection{Extraction of EOs by headspace solid-phase microextraction (HS-SPME)}

The solid-phase microextraction holder consistent match a replaceable extraction fibre, coated with $100 \mu \mathrm{m}$ polydimethylsiloxane (CAR/PDMS; Supelco) and extra block heater, headspace vials (7 $\mathrm{mL}$ ) and accessories. The solid phase microextraction device is the trace sampler to insert a quartz fiber coated with extraction phase, when the extraction equilibrium, enter the amount of analyte extraction phase [23]. The freshly harvested flowers $(1 \mathrm{~g})$ were ground in liquid nitrogen and immediately transferred into headspace vials. Samples were heated at $70{ }^{\circ} \mathrm{C}$ for $40 \mathrm{~min}$, and then, volatile substances were automatically collected by HS-SPME with simultaneous heating and agitation. The fibre was conditioned at $270{ }^{\circ} \mathrm{C}$ for $3 \mathrm{~min}$ to stop any contamination.

\subsection{GC-MS analysis}

Agilent-Technologies 6890 N/MS : 5973I N Network GC system equipped with a flame ionization detector and DB- 5 column $(30 \mathrm{~m} \times 0.25 \mathrm{~mm} \times 0.25 \mu \mathrm{m})$ were employed for the EOs analysis. Helium was the carrier gas with a flow rate of $1.0 \mathrm{~mL} / \mathrm{min}$. The column temperature was initially kept at $50{ }^{\circ} \mathrm{C}$ for $5 \mathrm{~min}$, gradually increased to $210{ }^{\circ} \mathrm{C}$ at $3{ }^{\circ} \mathrm{C} / \mathrm{min}$ rate, held to $10 \mathrm{~min}$ and finally raised to $230{ }^{\circ} \mathrm{C}$ at $15{ }^{\circ} \mathrm{C} / \mathrm{min}$. For GC-MS detection, an ionization system, with ion source temperature of $230{ }^{\circ} \mathrm{C}$ and ionization energy of $70 \mathrm{eV}$ were used. A scan rate of $0.6 \mathrm{~s}$ was applied covering a mass range from 35-400 amu. The standard mass spectral library NIST11 was used to identify individual components of the EOs. Mixed alkanes ( $\mathrm{C}_{8}-\mathrm{C}_{20}$, Sigma) were analyzed to determine Kovats retention indexes.

\subsection{Cytotoxicity assay}

MTT assay was employed to evaluate the effect of the EOs on the viability of human lung carcinoma A549 and H460 cells. 1.0×104 cells were plated in 96-well plates and treated with different concentrations of the EOs for $24 \mathrm{~h} .5 .0 \mathrm{mg} / \mathrm{mL}$ MTT $(20 \mu \mathrm{L})$ was added to each well and cells were incubated for another $4 \mathrm{~h}$ at $37^{\circ} \mathrm{C}$. The reaction was terminated by addition of $150 \mu \mathrm{L}$ DMSO and optical density at $570 \mathrm{~nm}$ was determined on a microplate reader (BioTek). 50\% inhibitory concentration ( $\left.\mathrm{IC}_{50}\right)$ was calculated from growth-inhibitory curves of cells by SigmaPlot 12.5 software.

4.5. Cell nucleus morphology observed by fluorescence staining

A549 and H460 (2.5×105 cells/well) were seeded into 6-well plates and incubated to $90 \%$ confluence. Subsequently, the cells were treated with different concentrations $(0,15.0,30.0,60.0$ $\mu \mathrm{L} / \mathrm{mL})$ of the EOs for $24 \mathrm{~h}$, and then indirectly incubated with Hoechst $33342(20 \mu \mathrm{g} / \mathrm{mL})$ for $30 \mathrm{~min}$ in the dark. The dyed fluorescent cells were observed under a fluorescence microscope (Olympus Co., Japan).

\subsection{Quantitative analysis of apoptosis by flow cytometry}


Apoptosis was monitored using the common Annexin V-FITC/PI detection kit (BD, Biosciences Pharmingen) as described by the manufacture's instruction. A549 and H460 cells in 6-well plates were treated with different concentrations of the EOs for $24 \mathrm{~h}$, collected and washed twice with PBS, gently resuspended in AnnexinV-binding buffer, and incubated with Annexin V-FITC and PI in dark for $10 \mathrm{~min}$. The fluorescent intensity of surface exposure of phosphatidylserine (PS) by apoptotic cells was measured by flow cytometry with a Coulter Cytomics FC500 through quadrant statistics for necrotic and apoptotic cell populations. Data were analyzed using BD Accuri ${ }^{\mathrm{TM}}$ C6 software (Accuri Cytometers, New Jersey, USA).

\subsection{Cell cycle distribution}

A549 and H460 cells (2.5×10 cells/well) in exponential growth were seeded in 6-well plates and treated with different concentrationsof the EOs for $24 \mathrm{~h}$. After incubation, the cells were collected, centrifuged and fixed with ice-cold $70 \%$ ethanol for $4 \mathrm{~h}$, then incubated with $20 \mu \mathrm{g} / \mathrm{mL}$ RNase A and $10 \mu \mathrm{g} / \mathrm{mL}$ propidium iodide (PI) for $30 \mathrm{~min}$ in the dark. The stained cells of cell cycle phase distribution and hypodiploid DNA were detected by flow cytometer (BD, FACSAria) at $488 \mathrm{~nm}$ and analyzed with FlowJo software (FlowJo, Oregon, USA).

4.8. Cell protein extraction and immunoblotting

Immunoblotting was performed as described previously [20]. After A549 and H460 cells were treated with the EOs for $48 \mathrm{~h}$. They were then resuspended in cold PBS after removal of the nutrient solution, and then centrifuged at $1500 \mathrm{rpm}$ for $5 \mathrm{~min}$ and lysed in RIPA lysis buffer with freshly added $100 \mathrm{mM}$ PMSF by ice bath for about $30 \mathrm{~min}$; afterwards, the protein supernatant was centrifuged at $12000 \mathrm{rpm}$ for $10 \mathrm{~min}$ at $4{ }^{\circ} \mathrm{C}$. The protein supernatant was quantified using a BSA standard curve. The proteins were denatured with loading buffer at $100{ }^{\circ} \mathrm{C} .40 \mu \mathrm{g}$ protein was separated by using 10-12\% SDS-PAGE and transferred to PVDF membranes (Millipore Corporation, USA). The membranes were blocked with 5\% skim milk (BD Biosciences, Franklin), which dissolved in $\mathrm{pH}$-adjusted TBST at room temperature for $2 \mathrm{~h}$. The membranes were incubated with diluted primary antibodies including Caspase-3, Caspase-8, Caspase-9, PARP, Bcl-2, Bax and $\beta$-actin diluted by $1: 1000$, followed by washing and incubation with HRP-linked anti-rabbit and anti-mouse IgG secondary antibodies diluted by 1:10000 in TBST. Protein bands were visualized with UltraECL (BI, Beit Haemek, Isreal) by super sensitive chemiluminescence imaging (Tanon Co., Shanghai, China).

\subsection{Statistical analysis}

Quantitative data are presented as mean \pm SEM from at least three independent experiments. Sigmaplot 12.5 software (Systat Software, Inc., Germany) was employed for graph construction. Student's t-test was used to evaluate the significance of differences in multiple comparisons, ${ }^{*} P<0.05$ and ${ }^{* *} P<0.001$ were considered as the statistical significance.

\section{Conclusions}

In summary, we provide a thorough phytochemical characterization of the flower EOs from Chinese P. tobira. In agreement with other studies, the EOs exhibited remarkable antiproliferative properties and induced apoptosis in cancer cells. However, in ecology, pharmacy and medicine, more data are needed to elucidate the role of individual compositions of the EOs or combinations of them for the observed biological activities.

Acknowledgments: This meaningful work was supported by a series of grants as follows: National Sciences Council of China (No. 81602648), Natural Sciences Fund of Zhejiang Province (No. LQ16H280004) and Talents Introduction of Funds Zhejiang Sci-Tech University (No. 14042218-Y). 
Author Contributions: Y.-F.Sun and Y.Sun conceived and designed the experiments. Z.-Q.W, P.-G.Xia, H.-T.Liu and Sh.-X.Wang carried out the experimental work, H.-F.Lu calculated and analyzed the data. M.W. and Z.-S.Liang wrote and revised the manuscript.

\section{Conflicts of Interest:}

The authors declare no any conflicts of interest with any parties or individuals.

\section{References}

1. Dib, R.A.E.; Eskander, J.; Mohamed, M.A.; Mohammed, N.M. Two new triterpenoid estersaponins and biological activities of Pittosporum tobira, 'variegata' (Thunb.) W. T. Aiton leaves. Fitoterapia 2015,106, 272-279.

2. Beckett, K.P.; Freer-Smith, P.H.; Taylor, G. Particulate pollution capture by urban trees: effect of species and windspeed. Global change biol. 2000, 6, 995-1003.

3. Lorenzini, G.; Grassi, C.; Nali, C.; Petiti, A.; Loppi, S.; Tognotti, L. Leaves of Pittosporum tobira, as indicators of airborne trace element and PM 10, distribution in central Italy. Atmospheric Environment 2006, 40, 4025-4036.

4. Oh, J.H.; Jeong, Y.J.; Koo, H.J.; Park, D.W.; Kang, S.C.; Khoa, H.V. Antimicrobial activities against periodontopathic bacteria of Pittosporum tobira and its active compound. Molecules 2014, 19, 3607-3616.

5. Ilaria, D.A.; Maria, C.D.G.; Francesco, G.; Domenico, M.C.D.; Nicolina, F.; Decimo, G.; Giovanni, I.; Giuseppe, B.; Raffaele, R. Isolation and structure elucidation of four new triterpenoid estersaponins from fruits of Pittosporum tobira AIT. Tetrahedron 2002, 58, 10127-10136.

6. Nickavar, B.; Amin, G.; Yosefi, M. Volatile constituents of the flower and fruit oils of Pittosporum tobira (Thunb.) Ait. grown in Iran. ZNC 2004, 59, 174-176.

7. Loukis, A.; Hatziioannou, C. Volatile constituents of Pittosporum tobira (Thunb.) Aiton cultivated in Greece. J. Essent. Oil Res. 2005, 17, 186-187.

8. Russo, A.; Formisano, C.; Rigano, D.; Senatore, F.; Delfine, S.; Cardile, V. Chemical composition and anticancer activity of essential oils of mediterranean sage (Salvia officinalis, L.) grown in different environmental conditions. Food Chem.Toxicol.2013, 55, 42-47.

9. Burt, S. Essential oils: their antibacterial properties and potential applications in foods-a review. Int. J. Food Microbiol. 2004, 94, 223-253.

10. Ebrahimabadi, A.H.; Ebrahimabadi, E.H.; Djafari-Bidgoli, Z.; Kashi, F.J.; Mazoochi, A.;Batooli, H. Composition and antioxidant and antimicrobial activity of the essential oil and extracts of stachys inflata benth from Iran. Food Chem. 2010, 119, 452-458.

11. Eunsil, K.O.; Choi, M.R.; Choi, K.M.; Cha, J.D. The effect of Pittosporum tobira against anti-Helicobacter pylori and anti-oxidant activity. IJVR 2014, 8, 4.

12. da Silva, J.K.R.; Andrade, E.H.A.; Mourao, R.H.V.; Maia, J.G.S.; Dosoky, N.S.; Setzer, W.N. Chemical profile and in vitro biological activities of essential oils of Nectandra puberula and N.cuspidata from the Amazon. NPC 2017, 12, 131-134.

13. Rivas da Silva, A.C.; Lopes, P.M.; Barros de Azevedo, M.M.; Costa, D.C.; Alviano, C.S.;Alviano, D.S. Biological activities of $\alpha$-pinene and $\beta$-pinene enantiomers. Molecules 2012, 17, 6305-6316.

14. Endalkachew, N.; Wink, M. Volatile components of four Ethiopian Artemisia species extracts and their in vitro antitrypanosomal and cytotoxic activities. Phytomedicine 2010, 17, 369-374.

15. Girola, N.; Figueiredo, C.R.; Farias, C.F.; Azevedo, R.A.; Ferreira, A.K.; Teixeira, S.F. Camphene isolated from essential oil of piper cernuum, piperaceae induces intrinsic apoptosis in melanoma cells and displays antitumor activity in vivo. BBRC 2015, 467, 928-934.

16. Sun, J. D-limonene: safety and clinical applications. J Clin Therapeutic. 2007, 12, 259.

17. Yao, Y.Q.; Ding, X.; Jia, Y.C.; Huang, C.X.; Wang, Y.Z.; Xu, Y.H. Anti-tumor effect of $\beta$-elemene in glioblastoma cells depends on p38 activation. Cancer lett. 2008, 264, 127-134.

18. Hengartner, M.O. The biochemistry of apoptosis. Nature 2000, 407, 770-776.

19. Amanzadeh, H.; Yamini, Y.; Moradi, M.; Asl, Y.A. Determination of phthalate esters in drinking water and edible vegetable oil samples by headspace solid phase microextraction using graphene/polyvinylchloride nanocomposite coated fiber coupled to gas chromatography-flame ionization detector. J. Chromatogr. A 2016, 1465, 38-46. 
10 of 10

20. Sun, Y.F.; Wink, M. Tetrandrine and fangchinoline, bisbenzylisoquinoline alkaloids from Stephania tetrandra can reverse multidrug resistance by inhibiting p-glycoprotein activity in multidrug resistant human cancer cells. Phytomedicine, 2014, 21, 1110-1119. 